Manuscript Number: HORTI21314

Title: Biochemical analyses and expression of cold transcription factors of the late PDO 'Calanda' peach under different post-harvest conditions

Article Type: Research Paper

Keywords: Prunus persica, chilling injury, cold storage, sugars, phenolics, organoleptic, real time-PCR, gene expression

Abstract: The peach of the designation of origin 'Calanda' that is much appreciated in the spanish market for its high fruit quality, is produced from a few very late ripening traditional cultivars. We characterized the organoleptic, nutritional and post-harvest quality of the 'Calanda' cultivars 'Calante' and 'Calprebor' following different harvest dates. The expression profile of genes associated with cold storage and chilling induction was studied under different post-harvest treatments in the two cultivars. Organoleptic and physicochemical damage were more severe under storage at $5^{\circ} \mathrm{C}$ than at $1^{\circ} \mathrm{C}$. The 'Calante' peaches showed less severity of chilling injury damage, better skin color, and higher phenolic content during cold storage, whereas the 'Calprebor' peaches showed greater firmness and higher glucose and fructose content during the post-harvest treatment. Cold transcription factors, CBF, and bzIP, increased cold storage and chilling injury resistance in the 'Calante' peaches. In addition, expression of GST22 may also promote resistance against cold damage, contributing to a higher firmness and phenolic content. 


\section{Biochemical analyses and expression of cold transcription factors of the late PDO 'Calanda' peach under different post-harvest conditions}

Arantxa Monteagudo ${ }^{1,2}$, Carolina Font i Forcada ${ }^{2}$, Gloria Estopañán ${ }^{1}$, Richard S. Dodd ${ }^{3}$, José Manuel Alonso ${ }^{1}$, María José Rubio-Cabetas ${ }^{1}$, Ángel Fernández i Marti ${ }^{3 *}$.

${ }^{1}$ Unidad de Hortofruticultura, Centro de Investigación y Tecnología Agroalimentaria de Aragón, Zaragoza, Spain.

${ }^{2}$ Dept. of Genetics and Plant Production, Estación Experimental de Aula Dei EEAD- CSIC, Avda. Montañana 1005, Zaragoza, Spain.

${ }^{3}$ Dept. of Environmental Science, Policy and Management, University of California Berkeley, USA.

*Corresponding author: Angel Fernandez i Marti: afernandezmarti@ berkeley.edu 


\section{ABSTRACT}

The peach of the designation of origin 'Calanda' that is much appreciated in the 6 Spanish market for its high fruit quality, is produced from a few very late ripening 7 traditional cultivars. We characterized the organoleptic, nutritional and post-harvest 8 quality of the 'Calanda' cultivars 'Calante' and 'Calprebor' following different harvest dates. The expression profile of genes associated with cold storage and chilling induction was studied under different post-harvest treatments in the $\mathrm{two}$ cultivars. Organoleptic and physicochemical damage were more severe under storage at $5^{\circ} \mathrm{C}$ than at $1^{\circ} \mathrm{C}$. The 'Calante' peaches showed less severity of chilling injury damage, better skin color, and higher phenolic content during cold storage, whereas the 'Calprebor' peaches showed greater firmness and higher glucose and fructose content during the post-harvest treatment. Cold transcription factors, $C B F$, and $b Z I P$, increased cold storage and chilling injury resistance in the 'Calante' peaches. In addition, expression of GST22 may also promote resistance against cold damage, contributing to a higher firmness and phenolic content.

Keywords: Prunus persica, chilling injury, cold storage, sugars, phenolics, organoleptic, real time-PCR, gene expression 


\section{Introduction}

Peach (Prunus persica (L.) Batsch) is one of the most cultivated fruit tree species around the world, with a large number of commercialized cultivars. In Spain, the only peach with a protected designation of origin (PDO), called 'Calanda peach', is particularly appreciated among consumers for its yellow, non-melting, high firmness flesh, large fruit size and particularly, for its good organoleptic attributes (Espada et al., 2009). One of the most characteristic agronomic practices for 'Calanda peach' is to introduce the fruit into a paper bag during "pit-hardening" to protect the fruit from infestation by the Mediterranean fruit fly (Ceratitis capitata), and to avoid direct contact with pesticides, climatic stresses and other external physical damage (Sharma et al., 2014). The paper bag remains on the fruit until harvest. Fruits acquire a homogeneous yellow color that is highly appreciated by consumers. B e c a u se harvest can occur from September to mid-November, 'Calanda peaches' are one of the dominant products in the late fresh market (Polo and Albisu, 2012).

'Calanda peach' is the subject of an extensive breeding program that has included clonal selection from a collection of the population-cultivar 'Amarillo Tardío del Bajo Aragón' (Late yellow from Bajo Aragon), accessioned in Alcañiz (Teruel, Spain) (Alonso and Espiau, 2009; Espada et al., 2009). The Aragon Government protected seven clonal selections (three in 1999 and four in 2008) that are authorized as PDO 'Calanda'. Two of them, 'Calante' and 'Calprebor' cultivars, are the object of this study. Today, the breeding goals have evolved to satisfy the demands of consumers and overcome the loss of competitiveness at the international level. For this reason, it is necessary to implement post-harvest technologies in the breeding programs in order to obtain better post-harvest quality.

Quality is a complex character determined by genetic traits, maturity at harvest and other factors, such as environment and agronomical practices (Llácer et al., 2006; Crisosto and Valero, 2008). The success of a cultivar in the market will depend on four components of quality: organoleptic or sensorial quality (colour, size, firmness and flavor; Colaric et al., 2005), nutritional quality (macro and micro nutrients, and antioxidants; Prior and Cao, 2000), post-harvest quality (dehydration, mechanical damage, pathogen infections and physiological disorders; Lurie and Crisosto, 2005) and sanitary quality (Infante et al., 2008).

Changes in texture, aroma, colour, and taste are related to ethylene auto-catalysis while climacteric fruit is ripening. Climacteric fruit continues to ripen even after harvest 
(Dong et al., 2001). When the fruit has become desirable for consumption, it has the organoleptic attributes attractive for the consumer and it has reached commercial maturity. The European Union has established that a peach fruit can be commercialized when it has a flesh firmness less than $6.5 \mathrm{~kg} / 0.5 \mathrm{~cm}^{2}$ and soluble solids (SSC) greater or equal to $8{ }^{\circ}$ Brix (Regulation Commission EC, No 1861/2004). Although recommendations for the optimal harvest and good consumer acceptance vary among countries and cultures (Kader, 2005), commercial requirements of the PDO 'Calanda' are more demanding than these standards $\left(<3 \mathrm{~kg} / 0.5 \mathrm{~cm}^{2},>12{ }^{\circ}\right.$ Brix, fruit diameter $>73 \mathrm{~mm}$ ), assuring its high quality and giving an added value to the fruits.

Peach is a highly perishable fruit at ambient temperatures, thus the storage and transport at low temperatures is necessary to make its shelf life longer in the market. However, several symptoms related to chilling injury develop after storage at low temperatures, such as graininess, flavorless, blushing, leatheriness, browning and/or mealiness (Crisosto et al., 2001). Breeders are interested in avoiding difficulties due to the complexity of quality traits. For this reason, every year there is increasing investment in studies concerning the genetic control of fruit quality traits (Horn et al., 2005; Llácer et al., 2006; Ogundiwin et al., 2008; Vizoso et al., 2009; Sánchez et al., 2013). Genetic analyses indicate that chilling injury in peach is a quantitative trait controlled by more than one quantitative trait locus (QTL) and several QTLs have been mapped onto the peach reference map (Pons et al., 2014). Despite this, little is known about molecular changes happening to fruits during post-harvest. There are different strategies that may solve this problem. By identifying the genes underlying the QTLs, it may be possible to find candidate genes that could be functionally related to the trait. A correlation between the trait and the polymorphism of a candidate gene could explain the existence of the QTL and indicate an approximation of the functional gene (Etienne et al., 2002).

Substantial variation in traits and content of metabolites among peach cultivars have been reported (Cantín et al., 2009a; Cantín et al., 2009b; Font i Forcada et al., 2014; Monti et al., 2016; Reig et al., 2015). There is general agreement among these research groups that differences among cultivars involve organoleptic properties, nutritional value, and defense against biotic and abiotic damage. For this reason, it is important to characterize the working material before applying any treatment.

The main aim of this study was to implement different post-harvest technologies to 'Calanda peach' in order to determine: (i) if there are differences in cold storage and 
108 chilling injury tolerance between the two cultivars selected from the native populationcultivar 'Amarillo Tardío del Bajo Aragón' that can be exploited in the breeding program, and (ii) to identify transcription factors and genes associated with these traits. To this end, a characterization of the organoleptic, nutritional and post-harvest quality of two cultivars with different harvest dates was carried out. In addition, an identification of genes associated with cold storage and chilling injury was undertaken, followed by determination of the expression profile of candidate genes related to post-harvest. This information will be useful in the future for the 'Calanda peach' breeding programs.

\section{Material and methods}

\subsection{Material and agronomic assay}

Assays were developed in two representative 'Calanda peach' cultivars (Prunus persica (L.) Batsch) from PDO Calanda: 'Calprebor', the earliest harvested and 'Calante', one of the latest harvested cultivars. Three hundred fruits of each cultivar were harvested in September and October 2013 in an experimental orchard in Alcañiz (Teruel, Spain).

Two assays were carried out between October and November 2013: chilling injury (at $5^{\circ} \mathrm{C}$ ) and cold storage (at $1^{\circ} \mathrm{C}$ ) (Figure S1). After each assay, fruits were characterized for fruit quality traits, peeled and cut into small slices. Two biological replications were collected and stored at $-20^{\circ} \mathrm{C}$ for phytochemical analyses and frozen at $-80^{\circ} \mathrm{C}$ for molecular studies.

\subsection{Chilling inducing assay}

Mature (ripe) fruits with uniform size and colour and showing no sign of damage were chosen. Five boxes with 12 mature fruits were stored at $5^{\circ} \mathrm{C}$, and evaluated after 14 and 28 days, and then placed at room temperature for 2 days (Chilling injury (CI): CI 0, CI 14, CI 14+2, CI 28, CI 28+2). At each sample time, one box was evaluated.

\subsection{Cold storage assay}

Fruits were divided into mature (ripe) and immature (unripe) sets based on external appearance: Colour, size, and firmness were determined to classify immature (green, small, firm) and mature fruits (yellow, big, less firm). Three boxes with 12 mature fruits and $12 \mathrm{immature}$ fruits were stored at $1{ }^{\circ} \mathrm{C}$ for 20 days and then they 
were placed at room temperature for 2 days (Cold storage (CS): Mature (M) - CS M0, CS M20, CS M20+2; Immature (I) - CS I0, CS I20, CS I20+2. At each sample time, one box was evaluated.

\subsection{Evaluation of fruit quality}

For each assay, weight loss and firmness of 10 fruits were measured. For colour, CIELAB coordinates of 10 fruits were obtained using a colorimeter (CR- 200 Minolta, Japan) to give the following measures: $\mathrm{L}^{*}$ (lightness), $\mathrm{a}^{*}$ (where negative values indicate greenness and positive values indicate redness) and $b^{*}$ (where negative values indicate blueness and positive values indicate yellowness). The measurement was made on opposite sides of each fruit, avoiding the suture line. The equipment was standardized every day before each measurement by using a calibration plate.

Flesh firmness $(\mathrm{N})$ was measured on two paired sides of each fruit, by removing a $1 \mathrm{~mm}$ thick disk of skin and using a penetrometer of $8 \mathrm{~mm}\left(0.5 \mathrm{~cm}^{2}\right)$ probe diameter (Penefel, Setop Giraud-Technologies, France). After skin colour and flesh firmness determinations, the fruits of the sample were peeled, and portions of the mesocarp were removed from opposite sides and cut into small pieces.

A composite sample was built by pooling all pieces from all the selected fruits and the soluble solids content was measured using a digital refractometer (Atago PAL-1, Japan). Data were expressed in ${ }^{\circ}$ Brix. Titratable acidity (TA) expressed as $\mathrm{g}$ malic acid/100 $\mathrm{g}$ FW was determined in $10 \mathrm{~g}$ of homogenized samples that were diluted with $90 \mathrm{ml}$ of distilled water, and microtitrated with $0.1 \mathrm{~N} \mathrm{NaOH}$ (Metrohm Ion analysis, 785 DPM Titrino, Switzerland). Ripening index was calculated based on the SSC/TA ratio. Chilling injury symptoms, including mealiness, graininess, loss of flavour (referred to as 'flavorless'), leatheriness, internal browning ('browning'), blushing, and a chilling injury index, were evaluated as described in Supplementary Table 1.

\subsection{Sugar content}

After cold-treatment, the fruits were peeled and cut longitudinally into two halves and a portion of the mesocarp was removed from each half and cut into small pieces. For each compound to be analyzed, a composite sample of $4 \mathrm{~g}$ was built by mixing all pieces from the selected fruits. This sample was frozen in liquid nitrogen and kept at $-20^{\circ} \mathrm{C}$ until analysis. The frozen samples were homogenized for $30 \mathrm{~s}$ 
using an Ultra- Turrax homogenizer (Heidolph) with $35 \mathrm{~mL}$ Milli-Q water.

The mix was shaken in a MultiReax (Heidolph $®$ ) for $15 \mathrm{~min}$ and centrifuged at 4000 $\mathrm{g}$ at $4^{\circ} \mathrm{C}$ for 15 minutes more. The supernatant was recovered and filtered using a 0.45 $\mu \mathrm{m}$ Sartorius filter

An aliquot of $20 \mu \mathrm{L}$ of the extract was taken and injected into a $\mathrm{High}$ performance liquid chromatography (HPLC 360; Kontron, Milan, Italy), equipped with a double-piston bomb, auto-injector and an oven at $85^{\circ} \mathrm{C}$. An ionic exchange column Tracer Carbosep CHO-682 LEAD was used.

Glucose, fructose, sucrose and sorbitol were separated and detected by their refraction indices with a detector ERC-7512 (Erma Inc., Tokyo, Japan). Water Milli-Q de-gassed in a vacuum was used as solvent to inject the samples at a flow of 0.4 $\mathrm{mL} / \mathrm{min}$. Identification of chromatographic peaks was based on the retention time compared with known standards (Merck, Darmstadt, Germany). Results were expressed in $\mathrm{g} / 100 \mathrm{~g}$ fresh weight.

\subsection{Total phenolic content}

Total phenolic content was measured according to the Folin-Ciocalteau method. Freeze product (4 g) was homogenized using an Ultra-Turrax Heidolph homogenizer in $15 \mathrm{~mL}$ of solvent $\mathrm{HCl} 0.5 \mathrm{~N}$ in $\mathrm{CH}_{3} \mathrm{OH} 80 \%$. The sample was centrifuged at $4000 \mathrm{xg}$ (times gravity) for 20 minutes at $4^{\circ} \mathrm{C}$. After centrifugation, 0.5 $\mathrm{mL}$ were taken and $8 \mathrm{~mL}$ of water Milli-Q and $0.5 \mathrm{~mL}$ of Folin-Ciocalteau $0.25 \mathrm{~N}$ reagent (prepared diary at darkness) were added. The solution was shaken and after 3 minutes, one $\mathrm{mL}$ of $\mathrm{Na}_{2} \mathrm{CO}_{3} 1 \mathrm{~N}$ was added. After settling for 1 hour at room temperature, absorbance was measured in a spectrophotometer at $725 \mathrm{~nm}$.

In parallel, every day the standard calibration curves, using gallic acid in $\mathrm{CH}_{3} \mathrm{OH}$ $80 \%$ as a solvent, were prepared. The content of total phenolics was expressed as $\mathrm{mg}$ gallic acid equivalents (GAE)/100 g fresh weight.

\subsection{Real-Time q-PCR Analysis}

Total RNA of 'Calante' cultivar was extracted from $1 \mathrm{~g}$ of the mesocarp and then frozen in liquid nitrogen and stored at $-80^{\circ} \mathrm{C}$. Two biological replicates were performed following the method described by Meisel et al. (2005). The quantity and purity of the RNA was measured by spectrophotometer ND-1000. RNA quality was also verified by agarose gel. Genomic DNA was removed from RNA samples by using a 
DNase kit (Turbo DNA-free, Ambion ${ }^{\circledR}$, Applied Biosystems), following the manufacturer's protocol.

One $\mu \mathrm{g}$ of total RNA was converted to cDNA using SuperScript III $1^{\text {st }}$ Strand Synthesis kit (Invitrogen) following the manufacturer's protocol and a dilution of 1:40 was carried out. Afterward, the conversion was probed by PCR by using housekeeping primers for the Actin gene (forward primer: CAGATCATGTTTGAGACCTTCATGT, reverse primer: CATCACCAGAGTCCAGCACAAT) and a subsequent agarose electrophoresis gel. The qRT-PCR was carried out using $1 \mu \mathrm{l}$ of cDNA and SYBR Green PCR master mix (Applied Biosystems), in a thermocycler ABI Prism 7500 (Applied Biosystems). Two biological replications and three technical replications were performed for each sample. The expression levels were calculated by the DD threshold cycle (ddCt) method, being relative to elF-4 as reference gene. Further details of the primers are presented in the Supplementary Table 2.

\subsection{Data Analysis}

Statistical analyses were performed using Genstat Discovery ( $\left.4^{\text {th }} \mathrm{Ed}\right)$. Values are referred to as means \pm SE. The analysis of variance (ANOVA) was developed assuming the following model: cultivar $(\mathrm{CV})+$ maturity $(\mathrm{M})+$ interaction $\left(\mathrm{CV}^{*} \mathrm{M}\right)+$ error. The variation in the experiment was considered significant when the p-value was less than 0.05 . treatment in “ $\mathrm{R}$ " ( $\mathrm{R}$ Core Team, 2017). When possible, t-tests were used to determine differences between control and treatment, if not, a Mann-Whitney test was applied. For gene expression, analyses were performed using $\mathrm{dCt}$ values (reference gene - target gene). Kendall's rank correlations were calculated using cor and rcor functions (Hmis package) and the corplot package was used to visualize the correlogram.

246 It was performed for 9 treatments (CI0, CI14+2, CI28+2, CSI0, CSI20, CSI20+2, CSM0, CSM20, CSM20+2) and one cultivar ('Calante') due to the need for paired data for phenotypic traits and molecular results (only $C B F$ and $b Z I P$ genes). The analysis was repeated for the CS treatment only, to obtain the relationship between traits and genes $(C B F, b Z I P$, and GST22) (It was not repeated for the CI treatment because more than 4 observations were required). 


\subsection{Characterization of cultivars}

'Calprebor' and 'Calante' cultivars, both from PDO Calanda, were characterized for physicochemical parameters for two maturity stages (immature and mature) of fruit after harvest.

The results obtained from the ANOVA model showed that both cultivars were significantly different in weight, firmness, color, individual sugars (except for sucrose and fructose) and total sugars; and total phenolic content, as shown in Table 1 (source of variation CV). Also, significant differences between maturity stages were found in firmness, redness and sucrose content (Table 1, source of variation $\mathrm{M}$ ), being higher in mature fruits than in immature ones for redness and sucrose. Finally, the interaction between cultivars and maturity (Table $\left.1, \mathrm{CV}^{*} \mathrm{M}\right)$ showed that both cultivars behaved differently during their growth on the tree. This interaction was significant for the following traits: weight, SSC, sucrose, glucose, sorbitol, total sugars and phenolic content. At both maturity stages, 'Calprebor was higher in firmness, greenness, glucose, sorbitol, total sugar and phenolic content. 'Calante' fruits were higher than 'Calprebor' in weight, lightness, and yellowness. Therefore, it is very difficult to compare both cultivars, harvested at different maturity stages. This result explains the variation between cultivars, but it did not explain the interaction between the cultivars. The interaction between $\mathrm{CV}$ and $\mathrm{M}$ is explained by the different evolution of both cultivars in their development on the tree. While 'Calprebor' fruit maintained a constant weight and SSC, 'Calante' fruit increased by about $50 \mathrm{~g}$ and almost $1^{\circ}$ Brix. Similarly, the content of sugars experienced a slight increase in 'Calprebor' while sucrose, glucose,sorbitol, total sugars, and total phenolic content increased strongly in 'Calante' after storage.

\subsection{Chilling-induced treatment}

Loss of weight due to chilling was gradual, reaching $23 \%$ at the end of storage in both cultivars (Fig. 1a). Also, a loss in firmness during the post-treatment (2 days at room temperature, Fig. 1b, CI 14+2, CI 28+2) relative to the chilling inducing treatment (CI 14 and CI 28, respectively) was detected in both cultivars. The cultivars did not show differences in sucrose (Fig. 1c), glucose (Fig. 1d) or fructose content (Fig. 1e) during the cold treatment or the post-treatment. Only the 'Calante' peaches showed a higher content of sorbitol during the post- treatment (Fig. 1f, CI 28+2). Both cultivars showed a drastic loss in phenolic content during storage at $5^{\circ} \mathrm{C}$ (Fig. $1 \mathrm{~g}, \mathrm{CI}$ 
14). Phenolic content was reduced faster in 'Calprebor' peaches than in 'Calante' peaches.

Chilling injury symptoms were intensified when storage at $5^{\circ} \mathrm{C}$ was longer (Fig. 3a). At $5^{\circ} \mathrm{C}, 41 \%$ of fruits showed chilling injury damage after 2 weeks and $83 \%$ after 4 weeks. This damage included symptoms of mealiness, leatheriness, internal browning, blushing, flavorless and graininess. The most significant disorders after 2 weeks were related to texture $(60 \%$ of the fruits showed mealiness and graininess) and flavor $(80 \%$ of the fruits). However, there were different symptoms that appeared after this period. Once the 4 weeks of storage had ended, fruits showed an increase in leatheriness $(60 \%$ of the fruits) and internal browning (83\% of the fruits). The less severe injury was found in the 'Calante' peaches during 2 weeks of storage at $5^{\circ} \mathrm{C}$ and two days at room temperature. However, the symptoms were as intensive in both cultivars after 4 weeks of storage and two days at room temperature. The cultivar 'Calprebor' suffered mealiness, graininess, and off-flavor at a higher level than the cultivar 'Calante'. Although the cultivar 'Calante' showed less severity in the majority of symptoms, the damage was more important in those related to firmness than with leatheriness.

In the cold storage assay, different behavior of both cultivars at the Immature (I) and Mature (M) stages were studied. These stages represent, not only unripe and ripe states, but also the "Ready to buy" and "Ready to eat" marketing stages (Crisosto and Valero, 2008) (shown in Table 1), respectively.

Loss of weight, experienced at $1{ }^{\circ} \mathrm{C}$, reached $8-10 \%$ at the end of the treatment (Fig.2a). Firmness during the cold treatment was reduced only in 'Calante' peaches, and during the post-treatment at room temperature in both cultivars (Fig. 2b).

Regarding the 'Calprebor' peaches, sucrose content was higher after 20 days at $1{ }^{\circ} \mathrm{C}$ (Fig. 2c, CS I20, and CS M20), and decreased during post-treatment (Fig. 2c, CS I20+2 and CS M20+2). On the other hand, the 'Calante' peaches did not experience this variation in sucrose content. 'Calante' peaches showed a constant value of glucose content during the treatment when the fruit was harvested immature, but it decreased in the postharvest when the fruit was harvested at a mature stage (Fig. 2d, CS M20+2). However, the 'Calprebor' peaches showed a striking variation in glucose and fructose after 20 days when the fruit was harvested at an immature stage (Fig. $2 \mathrm{~d}$ and 2e, CS I20). This increase was not important when fruit was harvested at a mature stage for this cultivar. 'Calante' showed a different fructose content only in the treatment of mature harvested fruits (CS M20), which was maintained during the 
325 post-treatment (CS M20+2). The content of sorbitol was constant at $1{ }^{\circ} \mathrm{C}$ for 326 'Calprebor' while it was reduced in immature harvested fruits (Fig. 2f, CS I20) and increased in mature harvested fruits (Fig. 2f, CS M20) for 'Calante' peaches. The phenolic content was reduced at $1{ }^{\circ} \mathrm{C}$ in both cultivars and was highly reduced in mature harvested fruits (Fig. 2g).

The fruits treated at $1{ }^{\circ} \mathrm{C}$ for the chilling injury analysis were tested in the cultivar 'Calante' (Fig. 3b). After 20 days of storage and two days at room temperature, both fruits showed the same symptoms of chilling injury. The index of damage was low for each symptom measured (less than 35\%) and high for mealiness $(60 \%$ and $80 \%$ for immature and mature, respectively).

\subsection{Expression Profile of Postharvest candidate genes}

Relative expression of two transcription factors (bZIP-like and CBF-like, Fig. 4) associated with cold resistance was analyzed by qRT-PCR at $5^{\circ} \mathrm{C}$ (Fig. 4a, Chilling inducing treatment) and $1{ }^{\circ} \mathrm{C}$ (Fig. $4 \mathrm{~b}$, Cold storage) in the 'Calante' cv. The chilling inducing treatment (Fig. 4a), showed significant differences for the $C B F$-like transcription factor across days of treatment. After two weeks in $5^{\circ} \mathrm{C}$ storage, the expression level was lower than at the beginning, and also lower than after 4 weeks of treatment.

The same behavior was observed at $1^{\circ} \mathrm{C}$ (Fig. 4b), where differences between maturity stages were tested. High expression levels of $C B F$ transcripts were found after 20 days at $1^{\circ} \mathrm{C}$. However, in the post-storage treatment at room temperature, the expression level of the same transcription factor was drastically reduced.

Expression levels of the $b Z I P$-like transcription factor increased during poststorage after 4 weeks at $5^{\circ} \mathrm{C}$ treatment (Fig. $4 \mathrm{a}$ ). In the treatment at $1^{\circ} \mathrm{C}$ (Fig. $4 \mathrm{~b}$ ), although expression levels were not significantly different between days of storage, there were differences between maturity stages.

The $P G D H$ gene expression was quantified only at $5^{\circ} \mathrm{C}$ (Fig.4a) due to the importance of the evolution of sugars during post-harvest at $5^{\circ} \mathrm{C}$. As storage advanced, $P G D H$ was up-regulated.

Expression levels of GST22 were only studied in the cold storage experiment (Fig. 4b), in order to determine if the oxidation process is relevant in post-harvest at different maturity stages, due to the effect of oxidation on organoleptic evaluation. Fruit harvested at physiological maturity maintained a constant expression during 20 days at 
$1^{\circ} \mathrm{C}$, but it was down-regulated in the post-harvest treatment. However, when fruit was harvested at maturity (more susceptible), expression levels were reduced during the storage and the post-storage at room temperature treatment.

\subsection{Correlations between traits and genes}

The average of the phenotypic data and the average of relative expression were used to develop a Kendall's Rank Correlation test. This test helps to resolve relations between trait-trait, trait-gene expression and gene expression-gene expression. Supplemental Figure 1 (Fig. S1) represents the general relationships between all phenotypic traits and a few genes (C-repeat binding factor $(C B F)$ and basic-leucine zipper domain $(b Z I P))$ taking into account observations for $\mathrm{CI}$ and $\mathrm{CS}$ assays for the 'Calante' cv. Regarding the traits, positive relations were found between TP, FF, and TA; between L and B, and between fructose, sorbitol, W and TS. Total phenolics, FF and TA were negatively related to $\mathrm{a}^{*}$ and RI. Glucose, $\mathrm{L}^{*}$ and $\mathrm{b}^{*}$ colour coordinates were negatively related to $\mathrm{W}$ and TS. Expression levels of $C B F$ were negatively related to SSC and positively related to $\mathrm{FF}$, while $b Z I P$ was negatively related to SSC and $\mathrm{b}^{*}$ colour coordinate.

Figure S2B showed similar relationships as Figure S2A but taking into account observations at CS for the 'Calante' cultivar. Positive relations were found between sucrose, SSC, TS and $\mathrm{a}^{*}$ and $\mathrm{b}^{*}$ color coordinates; sorbitol, fructose and TP, and sugars and TP with $\mathrm{W}, \mathrm{TA}$, and FF. RI and a* were negatively related to TP, W, TA, and FF. Figure S2B provides information about relations due to CS treatment, but also shows additional information about relationships between traits and GST22. The expression of GST22 was negatively related to SSC, a* color coordinate and RI, and positively with fructose, TP, W, TA and FF. The other two genes were related to traits mentioned above, but also new relationships between them were found. The $C B F$ factor was negatively related to $\mathrm{L}^{*}$ colour coordinated and the $b Z I P$ factor was negatively related to $\mathrm{a}^{*}$ and $\mathrm{b}^{*}$ colors coordinates and sucrose and $\mathrm{TS}$ and positively related to FF. 


\section{Discussion}

\subsection{Characterization of the two cultivars}

The peaches from PDO Calanda are usually known by their quality and late harvest date (from September to November). The two cultivars 'Calprebor' and 'Calante', (with earliest harvest date and latest harvest date, respectively), were characterized by their organoleptic and physicochemical parameters. Both of them developed from two clonal selections of the same cultivars, 'Amarillo tardío de Calanda', thus few differences between them were expected to be found. However, in the present study significant differences were found for weight, firmness, color, sugars and total phenolic content (Fig. 1). 'Calprebor' showed higher firmness, sugar content, and phenolics than 'Calante', while 'Calante' fruits were heavier with a more desirable color at the commercial maturity stage. The differences between maturity phases at harvest indicate that 'Calante' increased in weight and sugars, while 'Calprebor' did not. These results indicate that the duration of fruit growth of 'Calante' might be exploited to benefit the product quality in Calanda's peach.

Differences in physicochemical traits were evaluated when fruits were harvested at immature and mature stages: unripe and ripe according to Crisosto and Valero (2008). In each case, firmness and soluble solid content were in the range allowed in the EU for their commercialization (less than $6.5 \mathrm{~kg} / 0.5 \mathrm{~cm}^{2}$ and more or equal to $8{ }^{\circ}$ Brix, Regulation Commitment EC, No 1861/2004) (Table 1).

Sucrose was the principal sugar found at higher levels than other Spanish yellow peaches (Font i Forcada et al., 2014). 'Calprebor' was in the range of cultivars with high glucose at late harvest, while the range of 'Calante' was lower. Both cultivars had high levels of sorbitol and were richer in this compound than other late peach European and Californian cultivars (Gil et al., 2002; Scordino et al., 2012; Font i Forcada et al., 2014). Color and phenolic content were the only parameters that fell out of the range as reported elsewhere for 'Calanda's' peach (Ferrer et al., 2005) and other Spanish and foreign cultivars (Esti et al., 1997; Cantín et al., 2009a; Reig et al., 2013; Font i Forcada et al., 2014). The color may have been influenced by bagging the fruits. These cultivars differ from others in the high content of phenolic compounds that, from the nutritional point of view, are receiving more attention due to their potential health benefits (Prior and Cao, 2000).

Physiological ripeness and commercial maturity stages were significantly 
different in firmness, $\mathrm{a}^{*}$ color coordinate (relative to redness) and sucrose content. This analysis agrees with other studies, which have determined that it is not only firmness and color that are the most important parameters to determine the maturity of the fruit (Cascales et al., 2005), but also sugar content, as reported by Crisosto and Valero, (2008). Our analysis of variance revealed an interaction between $\mathrm{CV}^{*} \mathrm{M}$, indicating that the difference between mature and immature fruits depends on the cultivar. In this study, data showed that the cultivar 'Calprebor' suffered less change in weight, SSC, sugars, and phenolic content while ripening than 'Calante' (Table 1). These relations between changes in ripening values and cultivars are supported by studies in nectarine (Nogales- Delgado et al., 2014) and other fruits (Amiot et al., 1995; Howard et al., 2000; Siriwoharn et al., 2004). All these differences lead to the choice of methods to determine the optimal moment of fruit harvest (Crisosto and Valero, 2008), in particular, when post-harvest treatments are going to be applied.

\subsection{Postharvest affects the sugar composition of 'Calprebor' and reduces the phenolic content in both cultivars}

Fruit modifications during post-harvest have an effect on nutritional, quality and aroma traits, which depend mostly on the cultivar (Monti et al., 2016). Quality damage developed faster in the $\mathrm{CI}$ treatment $\left(5^{\circ} \mathrm{C}\right)$ than in the $\mathrm{CS}$ treatment $\left(1^{\circ} \mathrm{C}\right)$. The most affected parameters were fructose (increased more in 'Calprebor' cv.), firmness and total phenolic content (reduced in both cultivars). Loss of weight was more important when the treatment was longer, reaching $23 \%$ at the end of the treatment at $5^{\circ} \mathrm{C}$ and $8-10 \%$ at $1{ }^{\circ} \mathrm{C}$ (Fig. 1a). Progressive reduction of firmness was more intensive at $5^{\circ} \mathrm{C}$ than at $1^{\circ} \mathrm{C}$ (Fig. 1b). Crisosto et al. (1999) demonstrated that fruits suffered chilling injury symptoms at $5^{\circ} \mathrm{C}$ faster and more intense than at $0^{\circ} \mathrm{C}$. This group also remarked that late-harvest cultivars were more susceptible to $\mathrm{CI}$ at both temperatures, while we have seen that within late-harvested cultivars there are differences in susceptibility to chilling injury.

In the chilling induction and cold storage treatments, weight increased with a total content of sugars and decreased with glucose content (Fig. S2A), which increased each treatment, probably as a consequence of higher respiration and transpiration rates (Gupta and Jawandha, 2010). Some authors suggested that water balance and fruit transpiration affect fruit cell expansion and sugar concentration (via dilution) during fruit growing and after harvest (Morandi et al., 2007; Cirilli et al., 2016). Similar results for the content of sucrose, glucose, and fructose at low 
temperatures were found by Borsani et al. (2009), who suggested that sucrose is the principal source of carbon consumed after fruit harvest and it is turned into glucose and fructose by hydrolytic enzymes (invertase and sucrose synthase). These results agree with the increment of fructose content that we have found in our study, in particular for 'Calprebor' cv. (Fig. 1e and 2e), although no significant correlations were found.

Phenolic content was slightly reduced after 20 days of storage at $1{ }^{\circ} \mathrm{C}$ (Fig. $2 \mathrm{~g}$ ) and drastically decreased during the first weeks of storage at $5^{\circ} \mathrm{C}$ (Fig. $1 \mathrm{~g}$ ). These results agree with those reported by Asami et al. (2003) when the fruit was stored at $4^{\circ} \mathrm{C}$ but differs from the others, where postharvest at $2^{\circ} \mathrm{C}$ increase polyphenols content due to enzymatic hydrolysis (Di Vaio et al., 2008). Results indicate that cold treatment at $5^{\circ} \mathrm{C}$ is more aggressive for nutritional quality than the treatment at $1^{\circ} \mathrm{C}$. Both temperatures affect nutritional compounds in fruit, but the loss is less important at $1{ }^{\circ} \mathrm{C}$ than at $5^{\circ} \mathrm{C}$. The negative correlation found between total phenolics and redness (Fig. S2) could be due to their role in the development of pigmentation of the fruit skin (Cantín et al., 2011). However, although the evolution of phenolic content depends on the treatment, the behavior of the fruit under different treatments is cultivar-dependent (Zapata et al., 2014).

Evolution of immature and mature fruits was evaluated during CS treatment. However, small differences were found between both stages. It may indicate that low temperatures that delay CI symptoms have the same effect when the treatment is applied to mature or immature fruit.

\subsection{Chilling injury symptoms in 'Calante' are related to firmness}

While the time of storage at $5^{\circ} \mathrm{C}$ was increasing, the organoleptic damage was intensified. Most significant disorders after 2 weeks were related to texture and flavor while leatheriness and browning were more pronounced after 4 weeks. The type of symptoms developed during post-harvest treatments depended on the cultivar and the storage temperature (Crisosto et al., 1999). These symptoms together with the little blushing of the pulp, characteristic of late-season peach cultivars, were described in other studies (Crisosto et al., 1999; Cantín et al., 2010). Metabolism of phenolic compounds influenced the development of skin burning disease in peach (Cantín et al., 2011) and was related to browning and color in eggplant (Prohens et al., 2007). Cold storage affects the normal function of several cell wall-modifying enzymes, which leads to the internal breakdown of fruit tissues and, in consequence, reduces the 
quality of fruit (Brummell et al., 2004). Changes in sugars, such as fructose and xylose, may be related to changes in the cell wall, and in consequence to texture, while the composition of malic and citric acids could be responsible for the decrease in flavor (Monti et al., 2016).

Different susceptibility between cultivars was observed by Crisosto et al. (2001). In our work, less severity of the injury was found in 'Calante' cv. during the first 14 days of storage at $5^{\circ} \mathrm{C}$ and two days at room temperature (Fig. 3a). However, the symptoms were more drastic in both cultivars after 28 days of storage and two days at room temperature. Blushing and leathering were more affected in 'Calante' than in 'Calprebor', which might be related to the firmness of the cultivar (Table 1).

Chilling injury at $1{ }^{\circ} \mathrm{C}$ was tested in 'Calante' cv. in mature and immature fruits (Fig.3b). After 20 days of storage and two days at room temperature, both cultivars suffered equal chilling injury symptoms. Similar results were found at the firmmature stage after 3 weeks of storage at $0^{\circ} \mathrm{C}$ (Jin et al., 2009) and after 30 days at $0^{\circ} \mathrm{C}$ in nectarine (Dong et al., 2001). Although the effect of the cultivar on susceptibility to chilling injury must be considered (Crisosto et al., 2001), the maturity level does not seem to have an influence on the evolution of chilling injury at $1{ }^{\circ} \mathrm{C}$. The work of Amiot et al., (1995) in pears showed that the cultivar has more influence on browning than maturity stage.

It is possible to compare the effect of these treatments for 'Calante'. After 14 days at $5^{\circ} \mathrm{C}$ and two days at room temperature, leatheriness, flavorless, graininess and browning were higher than those found after 20 days at $1{ }^{\circ} \mathrm{C}$ and two days at room temperature. On the other hand, mealiness had more impact on the fruit stored at $1{ }^{\circ} \mathrm{C}$ than $5^{\circ} \mathrm{C}$. Comparing effects with 28 days treatment at $5^{\circ} \mathrm{C}$, at higher temperatures, the fruit suffered more than at $1{ }^{\circ} \mathrm{C}$. These results are similar to those described by Crisosto et al. (1999), suggesting that storage at lower temperatures contributes to better organoleptic fruit quality when fruits arrive to consumers.

\subsection{Transcription factors, sugars and oxidation are implied in the tolerance to cold stress.}

The response to low temperatures is activated by different families of transcription factors. Relative expression of two transcription factors ( $b Z I P$-like and $C B F$-like) related to cold resistance was analyzed by qRT-PCR for experiments at $1{ }^{\circ} \mathrm{C}$ and $5^{\circ} \mathrm{C}$ in 'Calante' $\mathrm{cv}$. In the chilling inducing experiment $\left(5^{\circ} \mathrm{C}\right), C B F$-like transcription factor showed a significant reduction of expression level during the days of treatment (Fig. 4a). The same behavior during the first weeks of storage at low 
temperatures was observed by Pons et al. (2014). Less expression was observed under $5^{\circ} \mathrm{C}$ than at $1^{\circ} \mathrm{C}$ (Fig.4a and $4 \mathrm{~b}$ ). The positive relationship between $C B F$ and SSC and negative relationship with flesh firmness agreed with results in other studies (Liang et al., 2013) showing that the treatment at $1{ }^{\circ} \mathrm{C}$ (chilling injury and $C B F$ ) could play a role in the resistance of the fruit to this injury through the biosynthesis of cryoprotective osmolytes like sucrose and proline during acclimatization to cold (Huang, 2006).

The Basic Zipper Leucine Promotor (bZIP) family is induced by ABA hormone, and it has been upregulated during fruit ripening. bZIP-like transcription factor increased in expression levels during post-storage after 4 weeks at $5^{\circ} \mathrm{C}$ (Fig. 4a). In the treatment at $1{ }^{\circ} \mathrm{C}$, although expression levels were not significantly different between days of storage, there were differences between maturity stages (Fig. 4b). This transcription factor is up-regulated in peach and is specific for the maturity stage (Lovisetto et al., 2013), showing maximum expression levels before reaching complete maturity. Negative correlations found between bZIP and sugars (Fig. S2A, B) are explained by the need for accumulation of sucrose, glucose, and fructose as signals of maturity, which is the start point of expression of bZIP-like genes (Lovisetto et al., 2013).

Phosphoglycerate-D-3 Dehydrogenase $(P G D H)$ participates in the conversion of glycerate to serine (Ho et al., 1999), an amino acid associated with metabolism at low temperatures (Nilo et al., 2010). It has been found to be under-regulated in post-harvest conditions, which could be related to firmness and aroma (Oms-Oliu et al., 2011). $P G D H$ gene expression was quantified only at $5^{\circ} \mathrm{C}$ due to the importance of sugar evolution during post-harvest at $5^{\circ} \mathrm{C}$, while as storage, advanced, $P G D H$ was upregulated (Fig. 4a). These data are similar to those exposed in the Chillpeach database (Ogundiwin et al., 2008). These results could be related to the increased levels of glucose in the post-harvest treatment, as a part of the metabolism of sugars.

Glutathione has a function in cellular redox control and detoxification. Glutathione-s-transferase (GST22) is a protein able to detoxify the toxic component in the cytosol (Nilo et al., 2010). Expression levels of GST22 were only studied in the cold storage experiment in order to determine if the oxidation procedure is relevant in post-harvest at different maturity stages, due to the effect of oxidation. Fruit harvested at physiological maturity maintained constant expression during 20 days at $1{ }^{\circ} \mathrm{C}$, but it was down-regulated in the post-harvest treatment (Fig. 4b). However, when fruits were harvested at commercial maturity (more susceptible), the expression levels were 
reduced during storage and post-storage at room temperature. Analyzing those results in Chillpeach database (Ogundiwin et al., 2008), it was confirmed that susceptible fruits have low levels of GST22, while tolerant fruits had higher levels. Dagar et al. (2012) have observed higher expression levels of GST22 in 'Yuval' nectarine (tolerant to chilling injury) than in 'Oded' peach (susceptible) at $4{ }^{\circ} \mathrm{C}$. In terms of maturity, results showed that fruit harvested at physiological maturity showed less chilling injury severity than fruit harvested at commercial maturity. Negative correlations have been found between GST22 expression and RI, while it was positively related with TP and FF (Fig. S2). Taking this into account, relative expression results are in line with the RI, TP and FF responses of 'Calante'. This might be supported by the function of GST22 in tolerance to low temperature stress, delaying maturity, and increasing phenolic content and firmness.

\section{Conclusions}

The cultivars selected from the breeding program of the PDO 'Calanda' have a high nutritional quality in terms of sugars and phenolic contents, providing them an added value. Postharvest has an effect on these components, more when storage is at $5^{\circ} \mathrm{C}$ than at $1^{\circ} \mathrm{C}$. Organoleptic damage depends on storage temperature and time of harvest showing that chilling injury is more aggressive when storage has been made at $5^{\circ} \mathrm{C}$ than at $1^{\circ} \mathrm{C}$. Loss of weight, possibly due to fruit respiration, is related to an evolution of content of sugars and phenolics, firmness and color. A good control of the humidity may help solve the problems derived from transport distances to potential consumers. Cultivars behave differently during their storage at low temperatures. 'Calante' cv. showed less severity of chilling injury damage and better color and high phenolic content during the cold storage, while 'Calprebor' cv. showed higher firmness, glucose and fructose content during the post-harvest treatment.

$C B F$ and $b Z I P$ are two transcription factor families that increase the cold storage and chilling injury resistance in 'Calante' cv. Expression of GST22 can also promote the resistance against cold damage, contributing higher firmness and phenolic content. These are three of many genes that may help in the breeding programs directed to find highvalue cultivars with higher post-harvest quality and longer cold storage. This information might be useful for breeders willing to incorporate fruit quality as one of the goals in their breeding programs. 
602

603

604

605

606

607

608

609

610

611

\section{Acknowledgements}

This work has been funded by the FITE 2013 from Instituto Aragonés de Fomento (IAF) and the Gobierno de Aragón, Spain (grupo A12). We appreciate the grant BIR (University of Lleida) for A. Monteagudo.

\section{Conflict of interest statement}

The authors declare no conflicts of interest. 


\section{References}

Alonso, J., Espiau, M., 2009. Peach germplasm from the Ebro Middle Valley in the CITA peach breeding programme. In: Company RS i (ed) XII ${ }^{\text {th }}$ Eucarpia Symp. on Fruit Breeding and Genetics. ISHS, 87-90.

Amiot, M.J., Tacchini, M., Aubert, S.Y., Oleszekz, W., 1995. Influence of Cultivar, Maturity Stage, and Storage Conditions on Phenolic Composition and Enzymatic Browning of Pear Fruits. J. Agric. Food Chem. 43,1132-1137.

Asami, D.K., Hong, Y.J., Barrett, D.M., Mitchell, A.E., 2003. Processing-induced changes in total phenolics and procyanidins in clingstone peaches. J. Sci. Food Agric. 83, 5663.

Borsani, J., Budde, C.O., Porrini, L., 2009. Carbon metabolism of peach fruit after harvest: changes in enzymes involved in organic acid and sugar level modifications. J. Exp. Bot. 60, 1823-37.

Brummell, D., Dal Cin, V., Lurie, S., 2004. Cell wall metabolism during the development of chilling injury in cold-stored peach fruit: association of mealiness with arrested disassembly of cell wall pectins. J. Exp. Bot. 55, 2041-52.

Cantín, C.M., Crisosto, C.H., Gradziel, T., Moreno, M.A. 2010. Chilling injury susceptibility in an intra-specific peach [Prunus persica (L.) Batsch] progeny. Postharvest Biol. Technol. 58, 79-87.

Cantín, C.M., Gogorcena, Y., Moreno, M.A., 2009a. Phenotypic diversity and relationships of fruit quality traits in peach and nectarine [Prunus persica (L.) Batsch] breeding progenies. Euphytica. 171, 211-226.

Cantín, C.M., Gogorcena, Y., Moreno, M.A., 2009b. Analysis of phenotypic variation of sugar profile in different peach and nectarine [Prunus persica (L.) Batsch] breeding progenies. J. Sci. Food Agric. 89, 1909-1917.

Cantín, C.M., Tian, L., Qin, X., Crisosto, C.H., 2011. Copigmentation triggers the development of skin burning disorder on peach and nectarine fruit [Prunus persica 
Cascales, A.I., Costell, E., Romojaro, F., 2005. Effects of the degree of maturity on the chemical composition, physical characteristics and sensory attributes of peach (Prunus persica) cv. Caterin. Food Sci. Technol. Int. 11, 345-352.

Cirilli, M., Bassi, D., Ciacciulli, A., 2016. Sugars in peach fruit: a breeding perspective.

Colaric, M., Veberic, R., Stampar, F., Hudina, M., 2005. Evaluation of peach and nectarine fruit quality and correlations between sensory and chemical attributes. J. Sci. Food Agric. 85, 2611-2616.

Crisosto, C.H., Mitchell, F.G., Ju, Z., 1999. Susceptibility to chilling injury of peach , nectarine, and plum cultivars grown in California. Hortic. Sci. 34, 1116-1118.

Crisosto, C.H., Valero, D., 2008. Harvesting and postharvest handling of peaches for the fresh market. In: Layne, D.R., Bassi, D. (eds) The Peach: Botany, Production and Uses, 2008th edn. CAB International, 575-596.

Dagar, A., Pons Puig, C., Marti Ibanez, C., 2012. Comparative transcript profiling of a peach and its nectarine mutant at harvest reveals differences in gene expression related to storability. Tree Genet. Genomes 9, 223-235.

Di Vaio, C., Graziani, G., Marra, L., 2008. Antioxidant capacities, carotenoids and polyphenols evaluation of fresh and refrigerated peach and nectarine cultivars from Italy. Eur. Food Res. Technol. 227, 1225-1231. 
Dong, L., Zhou, H.W., Sonego, L., 2001. Ethylene involvement in the cold storage disorder of "Flavortop" nectarine. Postharvest Biol. Technol. 23, 105-115.

Espada, J.L., Romero, J., Socias i Company, R., Alonso, J.M., 2009. Preview of the second clonal selection from the autochthonous peach population "Amarillos Tardíos de Calanda " (Late Yellow Peaches of Calanda). In: Socias i Company, R. (ed) XIIth Eucarpia Symp. on Fruit Breeding and Genetics. Acta Hort. 814, 251-254.

Esti, M., Messia, M.C., Sinesio, F., 1997. Quality evaluation of peaches and nectarines by electrochemical and multivariate analyses: relationships between analytical measurements and sensory attributes. Food Chem. 60, 659-666.

Etienne, C., Rothan, C., Moing, A, Plomion, C., Bodenes, C., Svanelle-Dumas, L., Cosson, P., Pronier, V., Monet, R., Dirlewanger, E., 2002. Candidate genes and QTLs for sugar and organic acid content in peach [Prunus persica (L.) Batsch]. Theor. Appl. Genet. 105, 145- 159 .

Ferrer, A., Remón, S., Negueruela, A.I., Oria, R., 2005. Changes during the ripening of the very late season Spanish peach cultivar Calanda. Sci. Hortic. 105, 435-446.

Font i Forcada, C., Gradziel, T.M., Gogorcena, Y., Moreno. M.A., 2014. Phenotypic diversity among local Spanish and foreign peach and nectarine [Prunus persica (L.) Batsch] accessions. Euphytica 197, 261-277.

Gil, M.I., Tomás-Barberán, F., Hess-Pierce, B., Kader, A.A., 2002. Antioxidant capacities, phenolic compounds, carotenoids, and vitamin $\mathrm{C}$ contents of nectarine, peach, and plum cultivars from California. J. Agric. Food Chem. 50, 4976-4982.

Gupta, N., Jawandha, S.K., 2010. Influence of maturity stage on fruit quality during storage of " Early Grande” Peaches. Not. Sci. Biol. 2, 96-99.

Ho, C., Noji, M., Saito, M., Saito, K., 1999. Regulation of serine biosynthesis in arabidopsis. J. Biol. Chem. 274, 397-402. 
Horn, R., Lecouls, A.C., Callahan, A., 2005. Candidate gene database and transcript map for peach, a model species for fruit trees. Theor. Appl. Genet. 110, 1419-28.

Howard, L.R., Talcott, S.T., Brenes, C.H., Villalon, B., 2000. Changes in phytochemical and antioxidant activity of selected pepper cultivars (Capsicum species) as influenced by maturity. J. Agric. Food Chem. 48, 1713-20.

Huang, B., 2006. Molecular responses and mechanisms of plant adaptation to cold. PlantEnvironment Interactions. 3, 55-62.

Infante, R., Martínez-Gómez, P., Predieri, S., 2008. Quality oriented fruit breeding : Peach [Prunus persica ( L .) Batsch ]. J. Food Agric. Environ. 6, 342-356.

Jin, P., Zheng, Y., Tang, S., 2009. A combination of hot air and methyl jasmonate vapor treatment alleviates chilling injury of peach fruit. Postharvest Biol. Technol. 52, 2429.

Kader, A.A., 2005. Increasing food availability by reducing postharvest losses of fresh produce. Acta Hortic 682, 2169-2176.

Liang, L., Zhang, B., Yin, X.R., et al., 2013. Differential expression of the CBF gene family during postharvest cold storage and subsequent shelf-Life of peach fruit. Plant Mol. Biol. Report 31, 1358-1367.

Llácer, G., Díez Niclós, M.J., Carrillo Becerril, J.M., Badenes, M.L., 2006. Mejora genética de la calidad en plantas, 1st ed. UPV, Valencia.

Lovisetto, A., Guzzo, F., Tadiello, A., Confortin, E., Pavanello, A., Botton, A., Casadoro, G., 2013. Characterization of a bZIP gene highly expressed during ripening of the peach fruit. Plant Physiol. Biochem. 70, 462-70.

Lurie, S., Crisosto, C.H., 2005. Chilling injury in peach and nectarine. Postharvest Biol. Technol. 37, 195-208.

Meisel, L., Fonseca, B., Gonzalez, S., Campos, R., Orellana, A., Retamales, J., Silva, H., 
2005. A rapid and efficient method for purifying high quality total RNA from peaches (Prunus persica) for functional genomics analyses. Biol. Res. 88, 38-83.

Monti, L.L., Bustamante, C.A., Osorio, S., Gabilondo, J., Lauxmann, M.A., Maulion, E., Valentini, G., Budde, C.O., Fernie, A.R., Lara, M.V., Drincovich, M.F., 2016. Metabolic profiling of a range of peach fruit cultivars reveals high metabolic diversity and commonalities and differences during ripening. Food Chem. 190, 879-888.

Morandi, B., Rieger, M., Grappadelli, L.C., 2007. Vascular flows and transpiration affect peach (Prunus persica Batsch.) fruit daily growth. J. Exp. Bot. 58, 3941-3947.

Nilo, R., Saffie, C., Lilley, K., Baeza-Yates, R., Cambiazo, V., Campos-Vargas, R., Gonzalez, M., Meisel, L., Retamales, J., Silva, H., Orellana, A., 2010. Proteomic analysis of peach fruit mesocarp softening and chilling injury using difference gel electrophoresis (DIGE). BMC Genomics 11, 43-59

Nogales-Delgado, S., Fuentes-Pérez, M.D.C., Ayuso-Yuste, C., Bohoyo-Gil, D., 2014. Study of different nectarine cultivars and their suitability for fresh-cut processing. Int. J. Food Sci. Technol. 49, 114-120.

Ogundiwin, E., Martí, C., Forment, J., Crisosto C.H., 2008. Development of chillpeach genomic tools and identification of cold-responsive genes in peach fruit. Plant Mol. Biol. 68, 379- 97.

Oms-Oliu, G., Hertog, M.L.A.T.M., Van de Poel, B., Ampofo-Asiama, J., Geeraerd, A.H., Nicolai, B.M.,2011. Metabolic characterization of tomato fruit during preharvest development, ripening, and postharvest shelf-life. Postharvest Biol. Technol. 62, 716.

Polo, C., Albisu, L.M., 2012. Wholesalers' reactions towards PDO Calanda peaches. Acta Hort. 962, 315-321.

Pons, C., Martí, C., Forment, J., Crisosto, C.H., Dandekar, A.M., Granell, A., 2014. A bulk segregant gene expression analysis of a peach population reveals components of 
the underlying mechanism of the fruit cold response. PLoS One 9, 3, e90706.

Prior, R.L., Cao, G., 2000. Antioxidant phytochemicals in fruits and vegetables : Diet and health implications. Hortic. Sci. 35, 588-592.

Prohens, J Rodríguez-Burrue, A., Raigón, M.D., Nuez, F., 2007. Total phenolic concentration and browning susceptibility in a collection of different varietal types and hybrids of eggplant: Implications for breeding for higher nutritional quality and reduced browning. J. Am. Soc. Hortic. Sci. 132, 638-646.

R Core Team, 2017. R: A language and environment for statistical computing.

Reig, G., Iglesias, I., Gatius, F., Alegre, S., 2013. Antioxidant capacity, quality, and anthocyanin and nutrient contents of several peach cultivars [Prunus persica (L.) Batsch] grown in Spain. J. Agric. Food Chem. 61, 6344-57.

Reig, G., Alegre, S., Gatius, F., Iglesias, I., 2015. Adaptability of peach cultivars [Prunus persica (L.) Batsch] to the climatic conditions of the Ebro Valley, with special focus on fruit quality. Sci. Hort. 190, 149-160.

Sánchez, G., Venegas-Calderón, M., Salas, J.J., Monforte, A., Badenes, M.L., Granell, A., 2013. An integrative "omics" approach identifies new candidate genes to impact aroma volatiles in peach fruit. BMC Genomics 14, 343.

Scordino, M., Sabatino, L., Muratore, A., Belligno, A., Gagliano, G., 2012. Phenolic characterization of Sicilian yellow flesh peach (Prunus persica L.) cultivars at different ripening stages. J. Food Qual. 35, 255-262.

Sharma, R.R., Reddy, S.V.R., Jhalegar, M.J., 2014. Pre-harvest fruit bagging: A useful approach for plant protection and improved post-harvest fruit quality - A review. J. Hortic. Sci. Biotechnol. 89, 101-113.

Siriwoharn, T., Wrolstad, R.E., Finn, C.E., Pereira, C.B., 2004. Influence of cultivar, maturity, and sampling on blackberry (Rubus L. Hybrids) anthocyanins, 
polyphenolics, and antioxidant properties. J. Agric. Food Chem. 52, 8021-30.

Swain, T., Hillis, W.E., 1959. The phenolic constituents of Prunus domestica. The quantitative analysis of phenolic constituents. J. Sci. Food. Agric. 10, 63-68.

Vizoso, P., Meisel, L.,, Tittarelli, A., Latorre, M., Saba, J., Caroca, R., Maldonado, J., Cambiazo, V., Campos-Vargas, R, Gonzalez, M., Orellana, A., Silva, H., 2009. Comparative EST transcript profiling of peach fruits under different post-harvest conditions reveals candidate genes associated with peach fruit quality. BMC Genomics 10, 423-434

Zapata, P.J., Martínez-Esplá, A., Guillén, F., Diaz-Mula, H.M., Martinez-Romero, D., Serrano, M., Valero, D., 2014. Preharvest application of methyl jasmonate (MeJA) in two plum cultivars. Improvement of fruit quality and antioxidant systems during postharvest storage. Postharvest Biol. Technol. 98, 115-122. 
Figure 1: Physiological traits during chilling inducing assay $\left(5^{\circ} \mathrm{C}\right)$. Twelve fruits were measured for weight and firmness, and two replicates are represent in sugars and phenolic content (mean $\pm \mathrm{SD}, * \mathrm{P}<0.05 ; * * \mathrm{P}<0.01$; *** $\mathrm{P}<0.005)$. Abbreviations: fw, fresh weight; TP, total phenolics; ns, not significant.

Figure 2: Physiological traits during cold storage assay $\left(1^{\circ} \mathrm{C}\right)$. Twelve fruits were measured for weight and firmness, and two replicates are represent in sugars and phenolic content (mean $\pm \mathrm{SD}, * \mathrm{P}<0.05 ; * * \mathrm{P}<0.01$; *** $\mathrm{P}<0.005)$. Abbreviations: fw, fresh weight; TP, total phenolics; ns, not significant.

Figure 3: Chilling injury symptoms. a) Chilling induced treatment at $5^{\circ} \mathrm{C}$. Symptoms evaluated after 14 and 28 days of storage and 2 days at room temperature in both cultivars. b) Cold storage treatment $1^{\circ} \mathrm{C}(\mathrm{CS} 20+2)$, in immature (CS I20+2) and mature fruits (CS M20+2) in cv. 'Calante'. Results are presented as a mean of 10 samples.

Figure 4: Expression levels of selected genes by qRT-PCR. a) Chilling induced treatment at $5^{\circ} \mathrm{C}$, evaluated after 14 and 28 days of storage and 2 days at room temperature in 'Calante' cv. b) Cold storage treatment $1{ }^{\circ} \mathrm{C}$, in immature (I) and mature fruits $(M)$ in 'Calante' cv. Results are presented as mean \pm SEM of three biological replicates.

\section{Supplementary Material}

Suplemental Figure 1: Scheme of post-harvest treatments.

Suplemental Figure 2: Kendall's Rank Correlations for CI and CS treatments (A) and for CS treatment alone (B).

Suplemental Figure 3: Description of chilling injury symptoms.

Suplemental Figure 4: Primer list. 
Table 1: Characterization of cultivars at different stage of ripeness. Sources of variation: $\mathrm{CV}$, cultivar; $\mathrm{M}$, maturity phase; $\mathrm{CV} * \mathrm{M}$, interaction

\begin{tabular}{|c|c|c|c|c|c|c|c|c|c|c|}
\hline \multirow[b]{2}{*}{ Trait } & \multirow[b]{2}{*}{ Units } & \multicolumn{3}{|c|}{ Immature fruit 'Ready to buy' } & \multicolumn{3}{|c|}{ Mature fruit 'Ready to eat' } & \multicolumn{3}{|c|}{$\begin{array}{l}\text { Sources of } \\
\text { variation }\end{array}$} \\
\hline & & 'Calprebor' & 'Calante' & Mean $\pm S E M$ & 'Calprebor' & 'Calante' & Mean \pm SEM & $\mathrm{CV}$ & M & $\mathrm{CV}^{*} \mathrm{M}$ \\
\hline Weight & g & $150.60 \pm 5.71$ & $307.01 \pm 20.68$ & $241.50 \pm 20.89$ & $149.70 \pm 6.62$ & $357.10 \pm 14.27$ & $444.50 \pm 17.83$ & ** & ns & *** \\
\hline Soluble solid content (SSC) & ${ }^{\circ}$ Brix & 17.60 & 13.80 & $15.70 \pm 1.90$ & 17.65 & 14.70 & $18.40 \pm 0.91$ & ns & ns & ** \\
\hline Firmness & Newtons & $6.65 \pm 0.25$ & $5.90 \pm 0.20$ & $6.30 \pm 0.15$ & $6.37 \pm 0.30$ & $5.31 \pm 0.41$ & $6.10 \pm 0.15$ & $* *$ & * & ns \\
\hline Titratable acidity (TA) & $\mathrm{g}$ malic acid/100 g & 3.03 & 3.67 & $3.32 \pm 0.28$ & 8.86 & 8.16 & $8.40 \pm 0.26$ & ns & ns & ns \\
\hline$L^{*}$ & Lightness & $66.49 \pm 0.57$ & $70.10 \pm 0.75$ & $69.03 \pm 0.46$ & $66.55 \pm 0.58$ & $70.24 \pm 0.82$ & $68.70 \pm 0.37$ & ** & ns & ns \\
\hline$a^{*}$ & Greenness/redness & $10.52 \pm 0.57$ & $-0.27 \pm 0.81$ & $3.53 \pm 0.99$ & $13.13 \pm 0.78$ & $3.77 \pm 0.73$ & $8.20 \pm 0.70$ & $\star \star$ & ** & ns \\
\hline$b^{*}$ & Blueness/yellowness & $52.86 \pm 0.69$ & $54.18 \pm 0.82$ & $53.50 \pm 0.49$ & $52.75 \pm 0.98$ & $56.05 \pm 0.91$ & $53.77 \pm 0.64$ & * & ns & ns \\
\hline Ripeness index (RI) & $\mathrm{SSC} / \mathrm{TA}$ & 1.53 & 1.62 & $1.57 \pm 0.04$ & 2.00 & 1.80 & $1.97 \pm 0.09$ & ns & ns & ns \\
\hline Sucrose & $\mathrm{g} / 100 \mathrm{~g}$ fresh weight & $8.68 \pm 0.17$ & $7.44 \pm 0.53$ & $8.06 \pm 0.39$ & $8.71 \pm 0.28$ & $9.03 \pm 0.69$ & $8.92 \pm 0.15$ & ns & * & *** \\
\hline Glucose & $\mathrm{g} / 100 \mathrm{~g}$ fresh weight & $1.26 \pm 0.63$ & $0.69 \pm 0.11$ & $0.98 \pm 0.17$ & $1.37 \pm 0.16$ & $0.78 \pm 0.07$ & $1.02 \pm 0.12$ & ** & ns & $\star \star \star *$ \\
\hline Fructose & $\mathrm{g} / 100 \mathrm{~g}$ fresh weight & $1.31 \pm 0.14$ & $1.18 \pm 0.52$ & $1.25 \pm 0.16$ & $1.38 \pm 0.05$ & $1.40 \pm 0.59$ & $1.39 \pm 0.11$ & ns & ns & ns \\
\hline Sorbitol & $\mathrm{g} / 100 \mathrm{~g}$ fresh weight & $2.92 \pm 0.13$ & $0.86 \pm 0.04$ & $1.89 \pm 0.60$ & $3.07 \pm 0.51$ & $1.11 \pm 0.19$ & $2.03 \pm 0.38$ & ** & ns & * \\
\hline Total sugars content & $\mathrm{g} / 100 \mathrm{~g}$ fresh weight & 14.16 & 10.18 & $12.17 \pm 1.20$ & 14.53 & 12.32 & $13.03 \pm 0.45$ & ** & ns & $* \star *$ \\
\hline Total phenolic content & $\mathrm{mg} \mathrm{GAE} / 100 \mathrm{~g}$ fresh weight & $86.60 \pm 2.41$ & $44.48 \pm 7.87$ & $65.54 \pm 12.39$ & $94.49 \pm 1.39$ & $75.95 \pm 1.04$ & $85.23 \pm 4.08$ & * & ns & *** \\
\hline
\end{tabular}


Figure 1. Physiological traits during chilling injury assay. Results are presented as mean \pm SD.

Twelve fruits were measured for weight and firmness, and a composite sample was used for SSC and TA measurements.

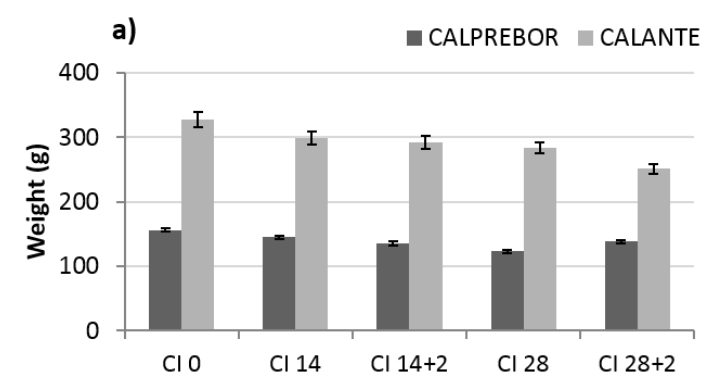

b)

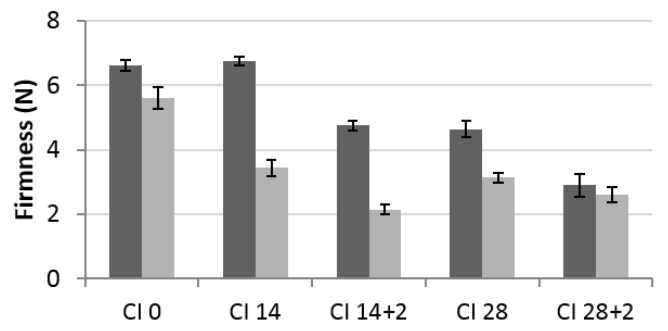

c)

d)
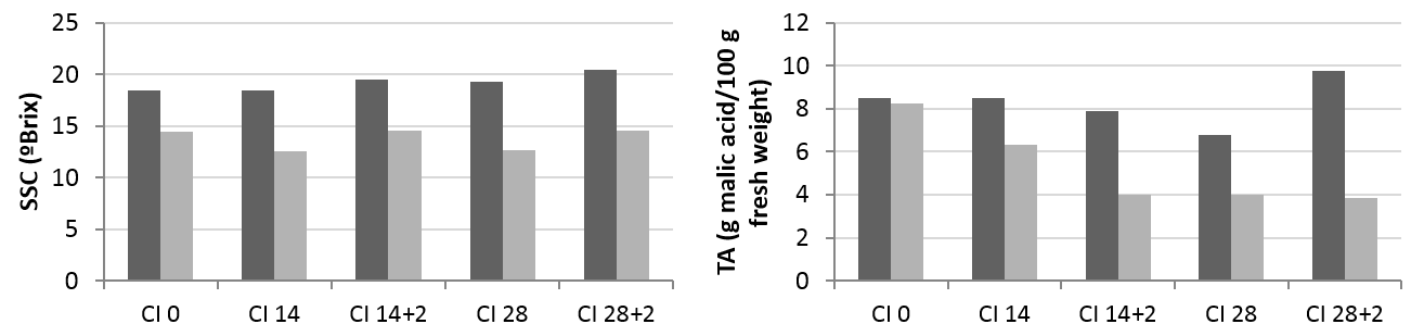
Figure 2. Sugars and phenolic content during chilling injury treatment. Results are presented as mean $\pm S D$ for two replicates.

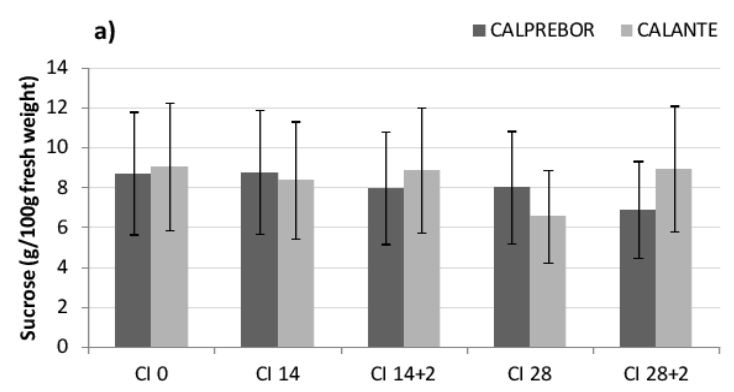

c)

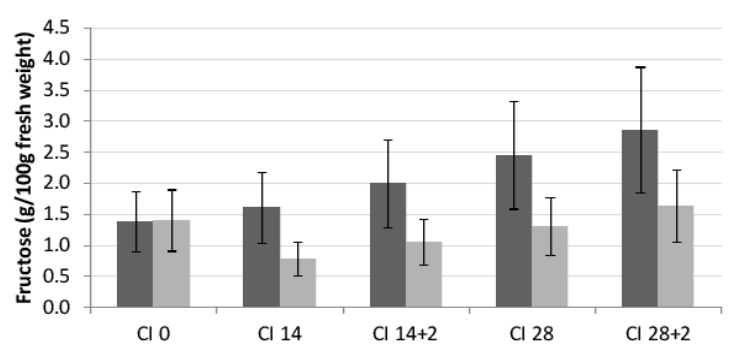

e)

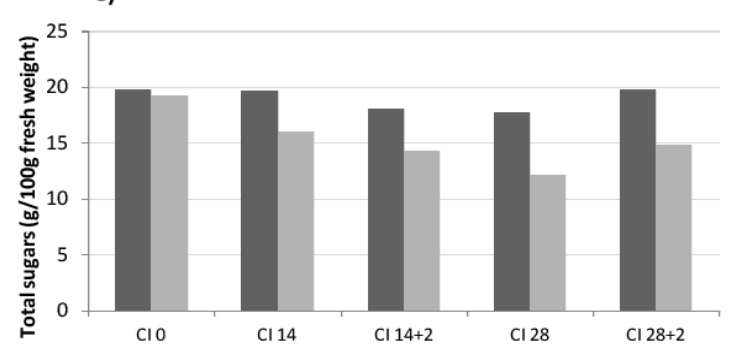

b)

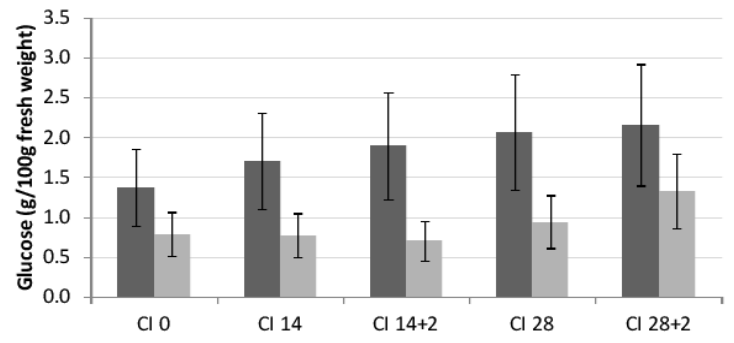

d)

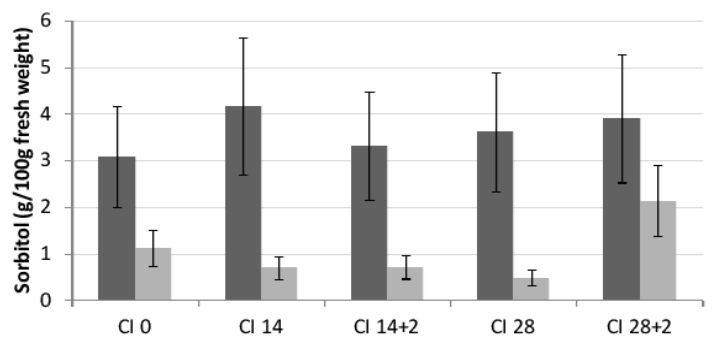

f)

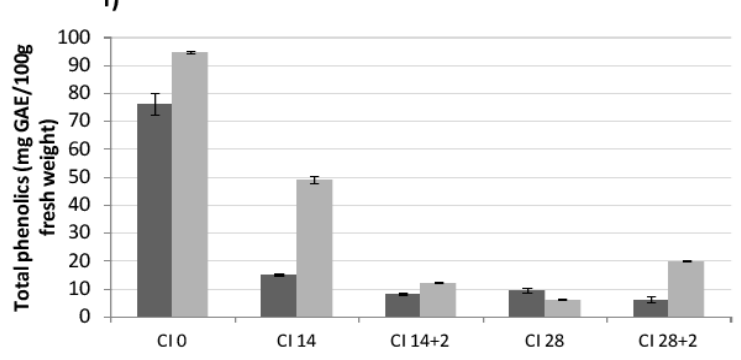


Figure 3. Chilling injury symptoms during post-harvest conditions at $5^{\circ} \mathrm{C}$. Results are presented as a mean of 10 samples.

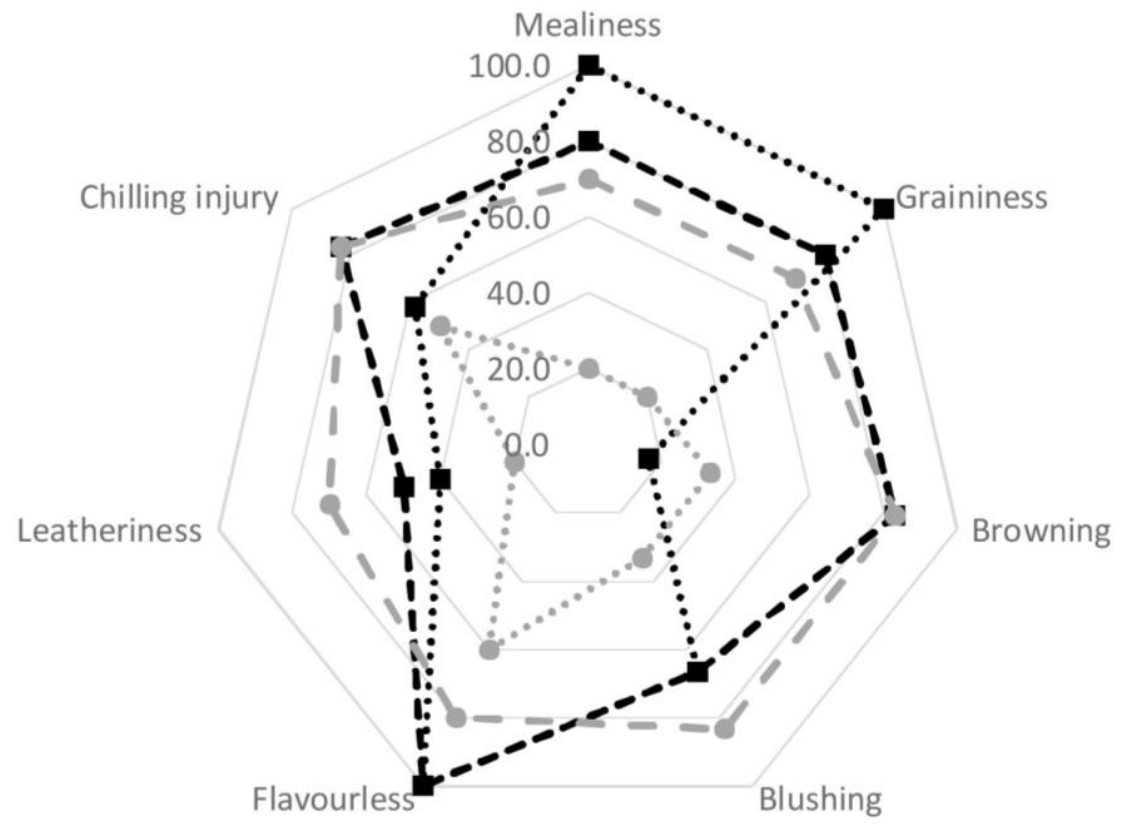

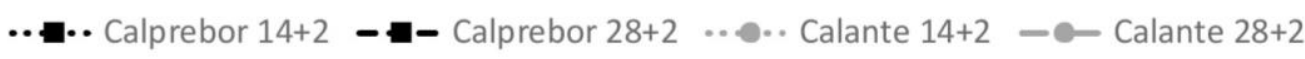


Figure 4. Physiological traits during shelf life assay. Results are presented as mean \pm SD. Twelve fruits were measured for weight and firmness, and a composite sample was used for SSC and TA measurements.
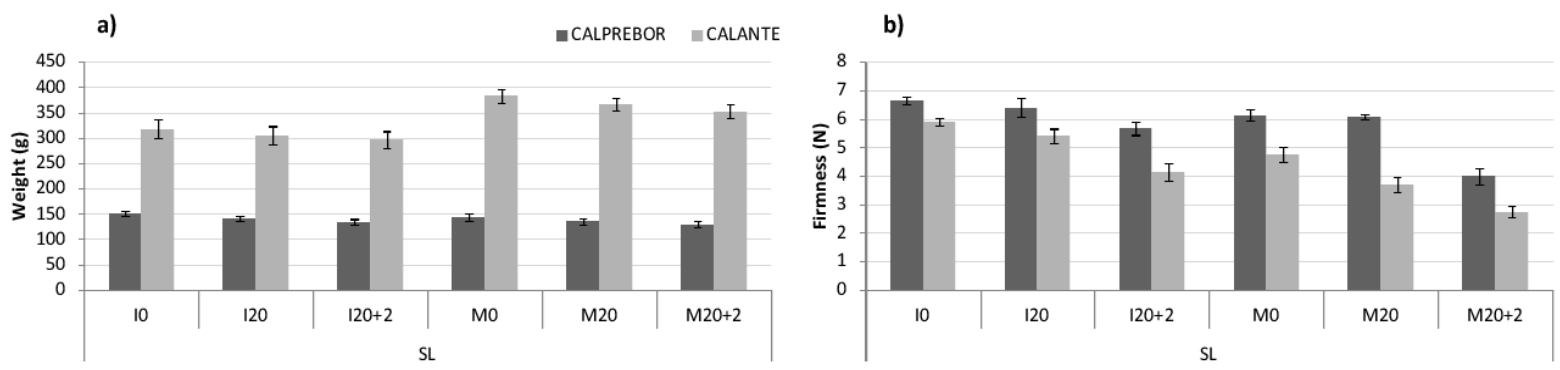

c)
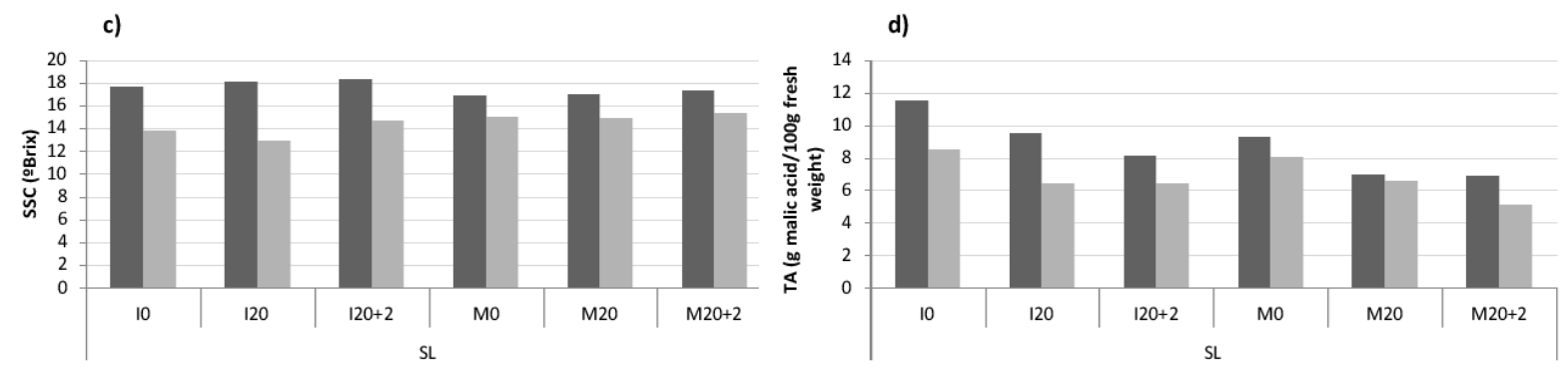
Figure 5. Sugars and phenolic content in shelf life assay. Results are presented as mean \pm SD for two replicates.

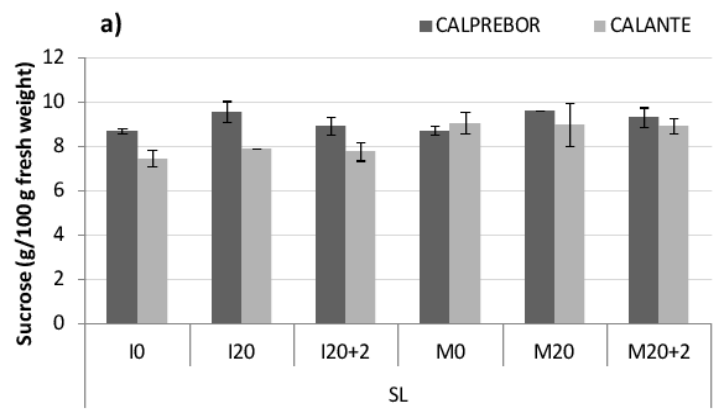

c)

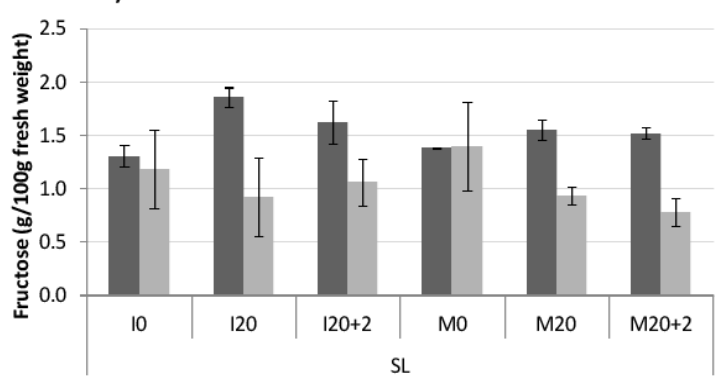

e)

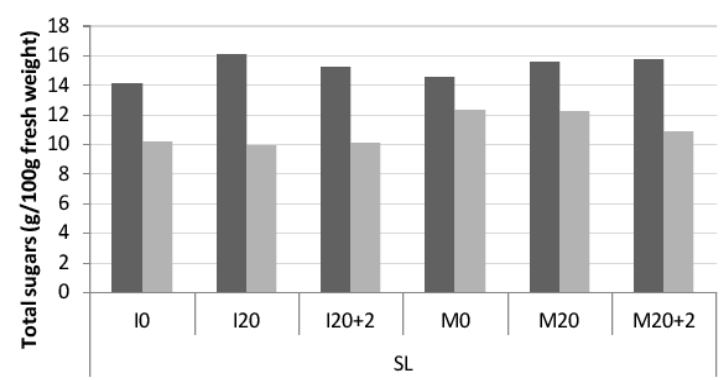

b)

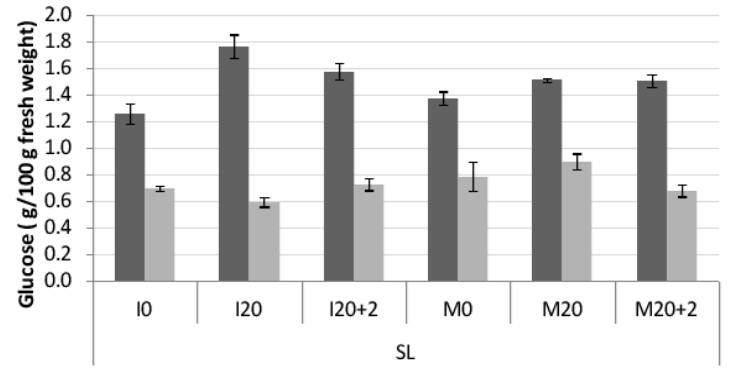

d)

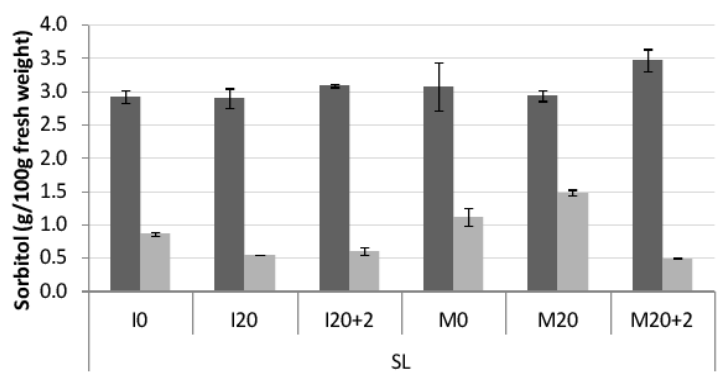

f)

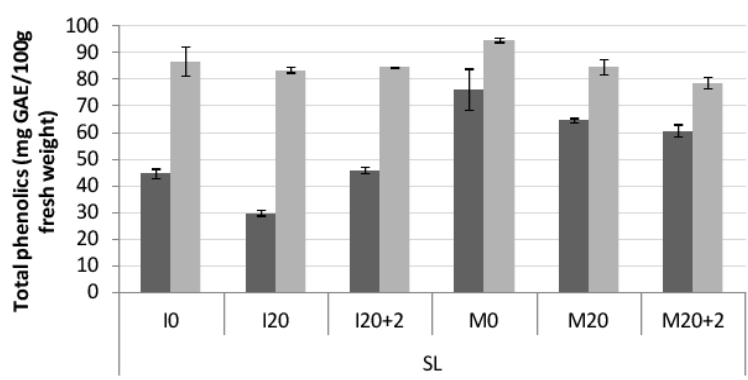


Figure 6. Organoleptic damage during post-harvest conditions at $1^{\circ} \mathrm{C}(S L 20+2)$, in immature (M1) and mature fruits (M2) in cv. 'Calante'. Results are presented as a mean of 10 samples.

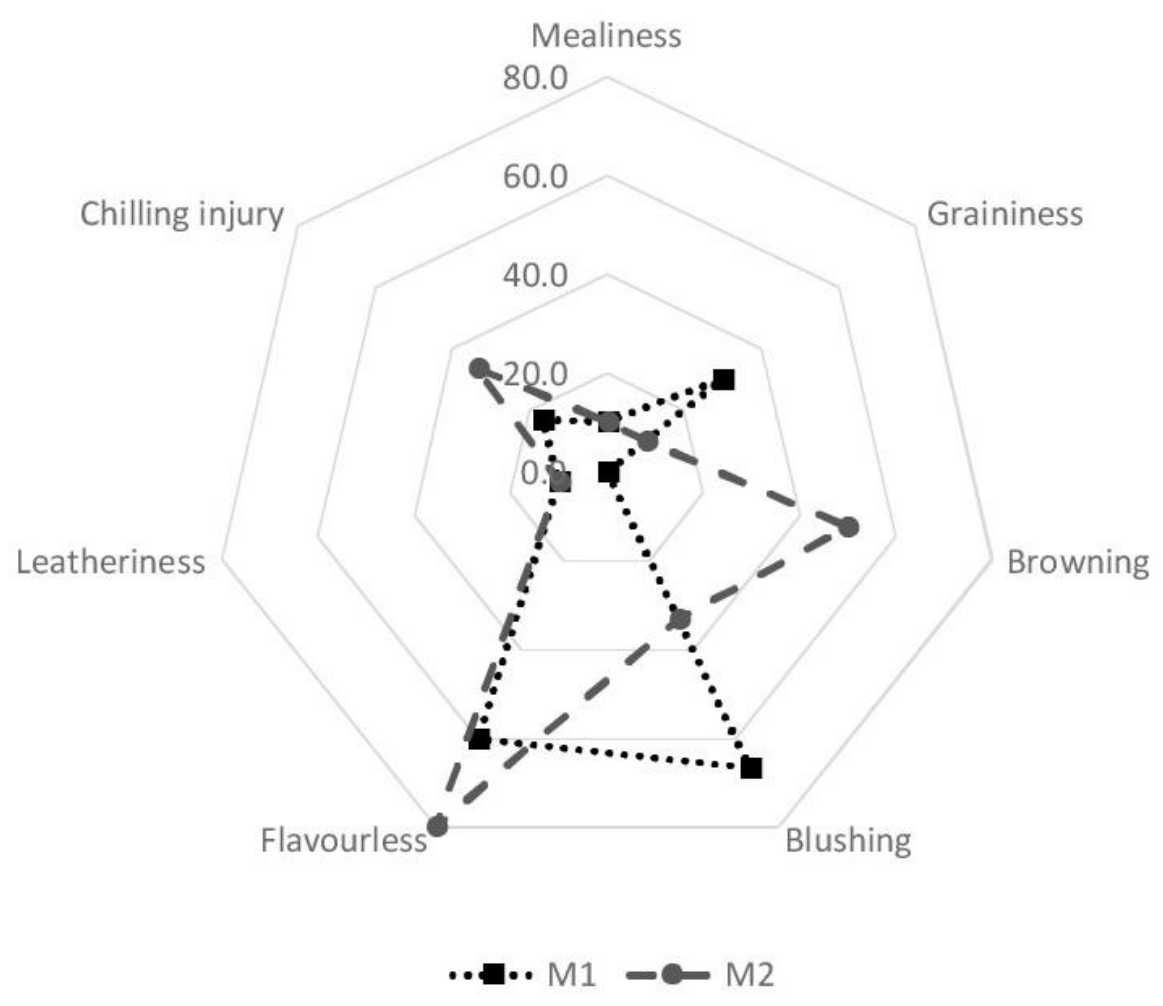


Figure 7. Expression levels of selected genes by qRT-PCR in chilling injury and shelf life assays.

Results are presented as mean \pm SEM of three biological replicates.
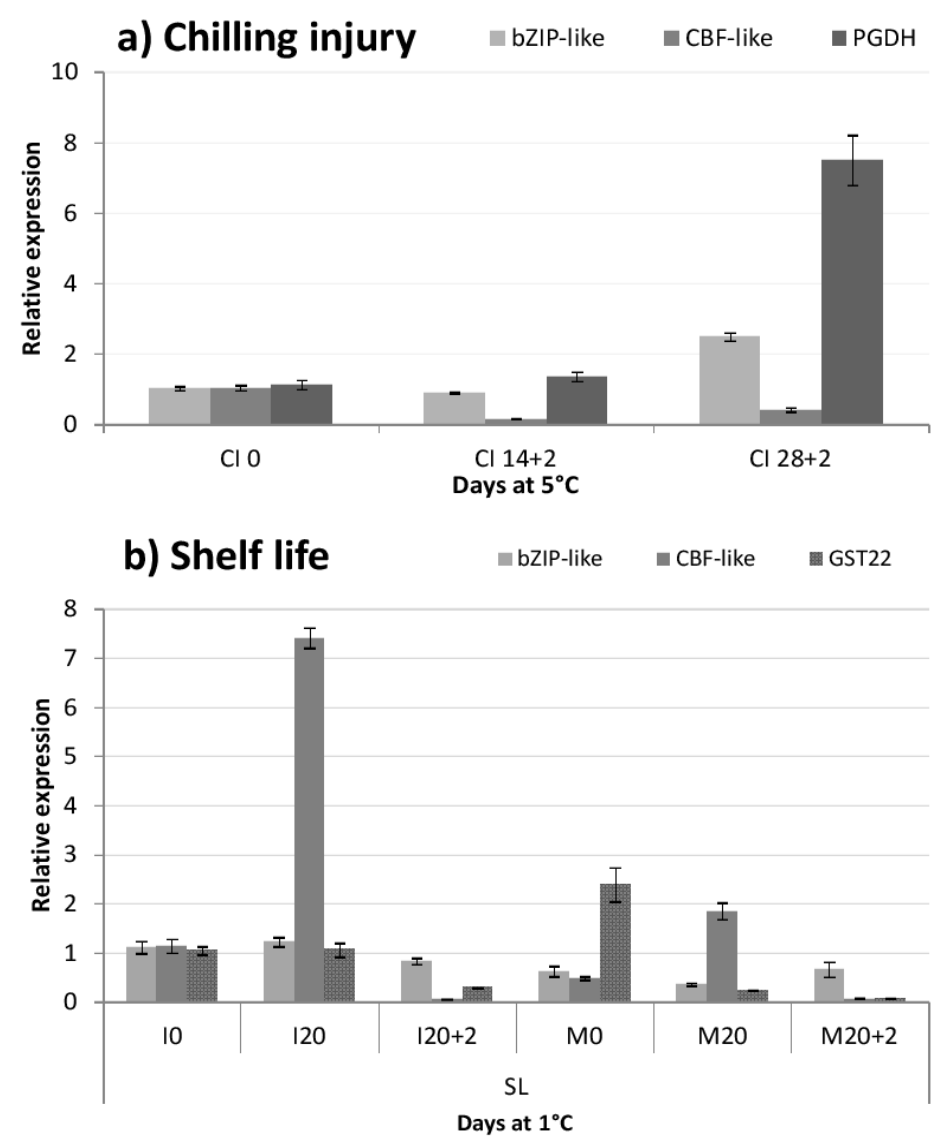
Fig.S1. Kendall's Rank Correlations for Cl and SL treatments (A) and for SL treatment alone (B).
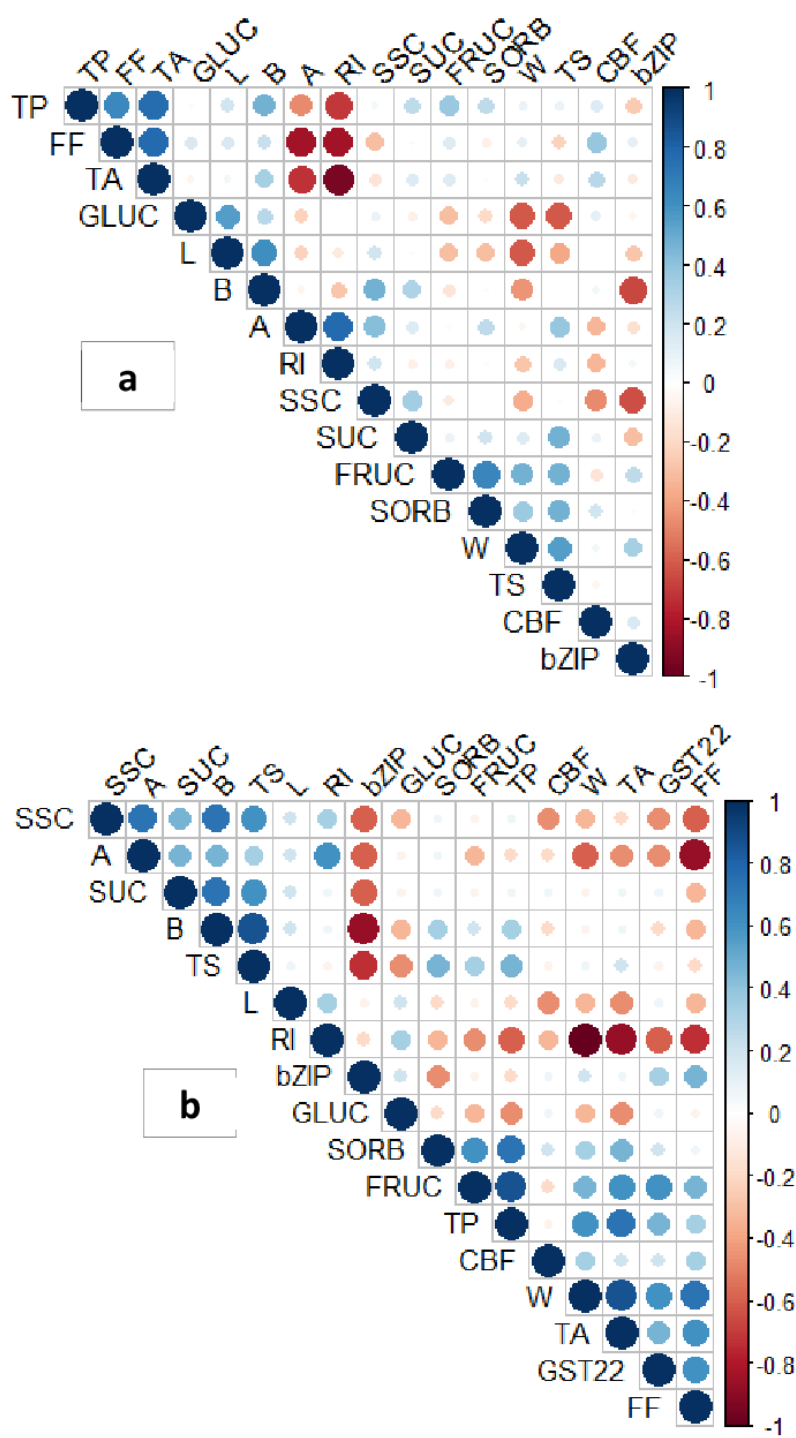